Journal of Economics and Behavioral Studies

Vol. 5, No. 3, pp. 136-147, Mar 2013 (ISSN: 2220-6140)

\title{
A Bound Test Analysis of Effects of Monetary Policy Shocks on Output and Prices in Nigeria
} 2000-2010

\author{
Apanisile Olumuyiwa Tolulope*, Taiwo Ajilore \\ Obafemi Awolowo University, Ile-Ife, Nigeria \\ *tolumid@yahoo.com
}

\begin{abstract}
The study examined the effects of monetary policy shocks on output and prices in Nigeria. This is done through an empirical analysis of the effects of anticipated and unanticipated monetary policies on output and prices. Quarterly data from 2000:1 to 2010:4 were used. The long-run ARDL estimates indicate positive and significant effects of anticipated monetary policy on output and prices while unanticipated monetary policy was insignificant. Thus, the findings provide a significant departure from the existing diversity of evidences of empirical literature on the monetary policy actions and macroeconomic variables nexus. The study therefore suggested the use of a one fit for all policy instrument in stimulating output growth and prices in the economy rather than using one specific measure which could lead to the failure of monetary policy in Nigeria.
\end{abstract}

Keywords: Monetary Policy Shocks, Output, Prices, Anticipated, Unanticipated

\section{Introduction}

Prior to 1986, monetary management in Nigeria depended on the use of direct monetary instruments such as credit ceiling, administered interest and exchange rates, as well as the prescription of cash reserve requirements in order to maintain price stability and a healthy balance of payments position that was achieved. The Structural Adjustment Programme (SAP) was adopted in 1986 and the objectives of monetary policy are stimulation of output and employment, moderation of inflation as well as reduction of pressure on the external sector and the promotion of domestic and external stability. In line with the general philosophy of economic management and monetary policy framework under SAP, the monetary policy framework in the post-SAP period (and up to 2000) focused on monetary targeting (CBN, 2009). The position of the policy during this period remained moderately restrictive so as to complement a disciplined fiscal policy in order to achieve moderation in inflationary pressures and ensure exchange rate stability. The main instrument of the market-based framework is the open market operations. This is complemented by reserve requirements and discount window operations. During this period, the results showed that while there was improvement in the macroeconomic environment, inflationary pressures and the disequilibrium in the external sector persisted. This led to the abandonment of monetary targeting approach alone as the monetary policy framework and inflation targeting approach was adopted in 2000 using interest rate as the policy instrument though, its operation is implicit. The policy measure was undertaken by CBN in order to influence real activities in the economy. Despite this inflation targeting monetary policy framework, evidence had shown that the inflation targeting arrangement still displayed less achievement in keeping inflation within the official target range because inflation rate had largely exceeded its $8.5 \%$ band since inception of the inflation targeting regime.

Lucas (1973) and Sargent and Wallace (1975) introduced Policy Ineffectiveness Proposition (PIP) in the late nineties to the monetary policy actions and macroeconomic variables nexus. The PIP hypothesis explains that in an economy where agents have rational expectation, anticipated monetary policy would have no effect on real variables since such changes were simply translated into price level changes. Unanticipated changes in monetary policy on the other hand, would have real effects because agents cannot distinguish between current, relative and absolute demand shifts. The empirical validity of this hypothesis has been the subject of many studies today with mixed results. For example, Yamak and Küçükkale (1998) and Odedokun (1988) rejected PIP hypothesis for Turkey and Nigeria respectively. They concluded that anticipated rather than unanticipated monetary policy exerted a significant expansionary impact upon real economic activity. Alogoskoufis (1982) and Saibu and Oladeji (2008) on the other hand, supported PIP hypothesis as conducted 
in Greece and Nigeria that unanticipated monetary policy had significant effect on real variables. Lee and Zilberfarb (1993) emphasized the need for verification of PIP validity in developing countries. This is because some of the crucial assumptions of the PIP are not necessarily valid for developing economies, given the fact that a large degree of government intervention in these countries might hinder quick adjustment of wages and prices thereby preventing market clearing. It is against this backdrop that this study examined the effect of monetary policy shocks on macroeconomic variables in Nigeria using inflation targeting monetary framework that emphasized short-term interest rate as policy instrument and also, tested the validity of PIP in Nigeria between $2000-2010$.

\section{Literature Review}

Friedman-Lucas supply theory was sketched out by Milton Friedman in 1968 and it was formalized by Robert Lucas in 1972. The theory was the first attempt to construct a theory where changes in the level of money supply could have real effects, with all markets clearing all the time. The key element of the theory is that workers have imperfect information. They observe current nominal wage (W) but they do not know the current price level (P), hence, they cannot observe current real wage

$\mathrm{w}=\frac{W}{P}$.

Suppose there are two shocks that may hit the economy, one is temporary change in Total Factor Productivity (TFP) and the other is permanent increase in money supply (M), workers cannot observe either Total Factor Productivity or Money supply during current period but they can make inferences about the chances of a particular shock based on the movement of the nominal wage W. According to the theory, when there is an increase in money supply(M) and current price level $(\mathrm{P})$, current real wage $(\mathrm{w})$ remains unchanged and as a result of this, current nominal wage increases (W). When Total Factor Productivity increases on the other hand, current real wage (w) increases and current price level (P) falls and nominal wage (W) probably increases. Workers care about real wages and under perfect information, an increase in money supply (M) will not change labour supply, hence, output remains unchanged. But when there is an increase in Total Factor Productivity, they know there is an increase in real wage and increase labour supply, hence output increases.

By comparison, utility optimization by workers requires knowledge of the general price level in order to calculate the purchasing power of the nominal wage. To know the price level, it requires knowledge of all the commodity prices, which is a degree of knowledge that each worker rarely, if ever, possesses. Hence, it is assumed that workers individually and on the average in the aggregate cannot predict the price level with sufficient accuracy, so that price level expected by workers ( $\mathrm{p}^{\mathrm{ew}}$ ) can differ from P. With these assumptions, the employment and output supply functions can be restated in the more specific form:

$\mathbf{n}^{*}=\boldsymbol{\theta}\left(\mathbf{P} / \mathbf{P}^{\mathrm{ew}}\right) \mathbf{n}^{*^{\prime}}>\mathbf{0}, \partial \mathbf{n}^{*} / \partial \mathbf{P}>\mathbf{0}, \partial \mathbf{n}^{*} / \partial \mathbf{P}^{\mathrm{ew}}<\mathbf{0}$

$\mathbf{y}^{*}=\varphi\left(\mathbf{P} / \mathbf{P}^{\mathrm{ew}}\right) \mathbf{y}^{* \prime}>\mathbf{0}, \partial \mathbf{y}^{*} / \partial \mathbf{P}>\mathbf{0}, \partial \mathbf{y}^{*} / \partial \mathbf{P}^{\mathrm{ew}}<\mathbf{0}$

If $\mathrm{P}>\mathrm{Pew}, \mathrm{w}<\mathrm{W}^{\mathrm{e}}$ so that labor will prove to be unexpectedly cheaper and firms will employ more than they had expected to employ. Hence, $\mathrm{y}^{*^{*}}>0, \partial \mathrm{y}^{*} / \partial \mathrm{P}>0$ and $\partial \mathrm{y}^{*} / \partial \mathrm{Pew}<0$. Equations (1) and (2) above are homogeneous of degree zero in $\mathrm{P}$ and $\mathrm{Pew}$. Since the expectations of both firms and workers are negatively related to output $y$, the notation can be simplified by replacing it by the single variable Pe. Therefore, the short-run equilibrium output function becomes:

$\mathrm{Y}^{*}=\mathrm{y}\left(\mathrm{P} / \mathrm{Pe}^{\mathrm{e}}\right) \partial \mathrm{y} / \partial \mathrm{P}>0, \partial \mathrm{y} / \partial \mathrm{Pe}^{\mathrm{e}}<\mathbf{0}$.

Where $\mathrm{P}^{\mathrm{e}}$ is now the expected price level for both firms and workers. The log-linear form of (3) is:

$L^{*} y^{*}=\ln y+\beta(\ln P-\ln P e) \beta>0$. (4)

Equation (4) is the expectations-augmented output function or Friedman-Lucas's supply function. Note the difference between y which designates the full-employment level (without errors in expectations), and *, which designates the short-run equilibrium level in the presence of errors in expectations. Correspondingly, we have for the level of employment:

$\ln \mathrm{n}^{*}=\ln \mathrm{n}+\alpha\left(\ln \mathrm{P}-\ln \mathrm{Pe}^{\mathrm{e}}\right) \alpha>0$.

equation (5) is the expectations-augmented employment function. Note that the price expectations in these equations refer to those incorporated in wage contracts. The economy deviates from its full-employment 
level due to errors in these expectations; compared with the full-employment level, output is greater if $\mathrm{P}>\mathrm{Pe}$ and lower if $\mathrm{P}<\mathrm{Pe}$. In the former case, real wages are lower than the full-employment real wage, making it attractive to hire more labor than in the error-free equilibrium; while the opposite holds in the latter case. The Friedman output model implies that anticipated monetary policy would not change output and unemployment. Furthermore, the Friedman-Lucas model asserts that the effects of monetary policy changes, both anticipated and unanticipated, must go through errors in the price expectations embedded in wage contracts and a subsequent decrease in real wages.

Several attempts had been made at establishing the empirical relationship between monetary policy shocks and real variables. Sargent and Wallace (1975) first attempted a direct test of the monetary policy ineffectiveness proposition. The study examined rational expectation, optimal monetary instrument and money supply rule in United States. They distinguished between unanticipated inflation and actual inflation as a cause of macroeconomic fluctuations in the United States. The outcome of their findings provided support for rational expectation hypothesis. Barro (1977) tested this rational expectation hypothesis for the second round after Sargent and Wallace. He examined unanticipated money growth and unemployment in United States and used annual data from 1941-1976 which he estimated using OLS. He replaced unanticipated inflation with unanticipated money growth and explained fluctuation in the real variables in the US economy. The study supports rational expectation in that it is unanticipated monetary policy only that influences output and employment. A similar result was obtained when Barro (1978) replaced unemployment with output. The proposition of the rational expectation hypothesis that anticipated short-run monetary stabilization policies did not influence real economic variables has been named the Macro Rational Expectations (MRE) hypothesis by Modigliani (1977). The empirical validity of MRE has been a central issue in modern stabilization theory. Barro (1977), and Barro and Rush (1980), tested the neutrality implication of the MRE hypothesis that anticipated monetary policy does not matter by using a two step procedure on annual data from 1941-1977 where the money growth equation was estimated by ordinary least squares with the residuals from this equation representing unanticipated movements in money growth, and the fitted values, anticipated money. A measure of real output was then regressed on anticipated and unanticipated money. For the United States, they found unanticipated money growth variables had significant explanatory power. However, anticipated money was insignificant.

Odedokun (1988) investigated the rational expectation hypothesis in Nigeria. The data set included inflation rate and four categories of real output namely; manufacturing output, real estate and construction, real GDP less primary production and overall real GDP. Odedokun admitted that his results were not robust and hardly conclusive but certain fairly reliable findings worthy of note emerge from his study. One of them was that anticipated monetary growth significantly influenced real variables when aggregate output was used. Another was that unanticipated monetary growth only affected inflation. However, evidence from his study also showed that unanticipated monetary growth exerted significant influence on manufacturing output. Lee and Zilberfarb (1993) analyzed the effect of unanticipated money on output, unemployment and prices in Korea using quarterly data for the 1964:2 -1987:4 periods. The empirical results tend to reject the rational expectation hypothesis in most cases. They show that both anticipated and unanticipated money affects output and prices, in contrast with the rational expectation hypothesis. Mixed results are obtained for the effect of monetary variables on unemployment. The statistical results show that the regular OLS two step estimates yield t-values which are upward biased by $0-27 \%$ as compared with the consistent estimates of the variance-covariance matrix that are obtained in this study. Ogungbenro et al (1995) examined the effects of monetary policy on unemployment. The study modified Barro (1977) and Wogin (1980) models to specify unemployment as a function of money supply, government expenditure and export earnings. The study also used OLS estimation technique on annual data from 1960 to 1993 for Nigerian economy. The results of their findings showed that monetary policy affected unemployment.

Saibu and Oladeji (2004) examined monetary policy and inflation control in Nigeria. The study investigated whether the ineffectiveness of monetary policy could be explained in term of incredibility of policy and loss of public confidence in these policies using quarterly data 1970-2000 from Nigeria economy. The study adopted the rational expectation theoretical framework and specified a monetarist's model with agents expectation formed rationally. This model was estimated using the Two Stage Least Square (TSL) technique. The findings from the empirical analysis showed that public response to government monetary policy was slow and with 
extreme long lags. It was also fund that unanticipated rather than the systematic component of monetary policy was significant in determining the inflation trend in Nigeria. This implies that monetary policy has been inconsistence and incredible over the sample period investigated in Nigeria. Khamfula (2006) investigated output growth forecasts as a result of dynamic interplay between money supplies and output growths of Southern African Common Monetary Area (SACMA) countries between 1981:1-2004:4 using Vector Error Correction Models (VECM). Countries involved are Namibia, Lesotho, South Africa and Swaziland. In general, the results showed that the forecasts for output growths in SACMA countries are quite similar to the actual values. Generally, the money supply changes have had a positive effect on output growths in all these SACMA countries. This may suggest that symmetric monetary shocks dominate in SACMA economies, which is a good indicator for an optimal currency area that would foster development in the region. Folawewo and Osinubi (2006) examined the efficacy of monetary policy in controlling inflation rate and exchange instability. The analysis performed was based on a rational expectation framework that incorporates the fiscal role o exchange rate. Using quarterly data spanning over 1980:1 to 2000:4 and applying times series test on the data used, the study showed that effects of monetary policy at influencing the finance of government fiscal deficit through the determination of the inflation-tax rate affects both the rate of inflation and exchange rate, thereby causing volatility in their rates. The study revealed that inflation affects volatility in its own rate, as well as the rate of real exchange.

Muhd Zulkhibri (2007) examined the causality relationship between monetary aggregates, output and prices in the case of Malaysia. The study used a Vector Auto-Regression (VAR) model applying the granger nocausality procedure developed by Toda and Yamamoto (1995). The results of the study indicated that a twoway causality running between monetary aggregates, M2 and M3 and output which are consistent with theoretically conjecture by Keynesian and Monetarist views whereas there is a one-way causality running from monetary aggregate, M1 and output. In addition, the results suggested that all monetary aggregates have a strong one-way causality running from money to prices but no evidence for the opposite causality. Oboe and Onafowora (2007) examined M2 Targeting, Money Demand, Real GDP Growth and inflation rate on the Nigerian economy since the introduction of the Structural Adjustment Program (SAP) in 1986. The study employed co-integration vector error correction methodology using quarterly data from 1986:1 to 2001:4. The results indicated that a long-run relationship exists between the real broad money supply, real GDP, inflation rate, domestic interest rate, foreign interest rate, and expected exchange rate. Furthermore, both the CUSUM and CUSUMSQ tests confirm the stability of the short- and long run parameters of the real money demand function. The stability of the real money demand function supports the choice of M2 as an intermediate target as Central Bank of Nigeria (CBN) attempts to manage inflation and stimulate economic activity in Nigeria. Our empirical analysis showed that the CBN was not strongly committed to its annual M2 money growth targets, but more importantly, the deviations from M2 target growth rates impacted real GDP growth rate and inflation rate adversely during the period.

Saibu and Oladeji (2008) investigated the openness and effects of monetary and fiscal policy shocks on the real output growth in Nigeria. It is a country specific, time series study that verified the implication of increasing economic Openness on the efficacy of monetary and fiscal policy. A modified GARCH model was used to estimate the anticipated and unanticipated shocks. Two measures of fiscal and monetary shocks were combined with openness and real oil price shocks in a VECM model to assess the effects of anticipated and unanticipated policy shocks on the output equations. The empirical results showed that anticipated and unanticipated fiscal and monetary shocks had no significant positive effects on real output. This suggests that the open macroeconomic version of the policy ineffectiveness proposition was valid for both monetary and fiscal policy shocks in Nigeria. This is in consonance with earlier works in this area. Furthermore, the degree of openness and oil price shocks had a negative implication on the efficacy of macroeconomic policy in Nigeria; also in agreement with the Dutch Disease Syndrome. Finally, the policy implication of this study therefore is that trade liberalization policy should be implemented cautiously. The Nigerian economy is weak to withstand the unwholesome consequences of full economic integration. A recent study by Chimobi and Uche (2010) examined the relationship between Money, Inflation and Output in Nigeria. The study adopted co-integration and granger causality test analysis. The co-integrating result of the study showed that the variables used in the model exhibited no long run relationship among each other. Nevertheless, money supply was seen to granger cause both output and inflation. The result of the study suggested that monetary stability can contribute towards price stability in the Nigerian economy since the variation in price level is 
mainly caused by money supply and concluded that inflation in Nigeria is to much extent a monetary phenomenon. Furthermore, the findings of the study support the money-prices-output hypothesis for Nigerian economy.M2 appeared to have a strong causal effect on the real output as well as on prices.

Mishra et al (2010) studied the relationship among money supply, price and output in India. Thus, this paper investigated the dynamics of the relationship between these macro-economic aggregates for India over the period 1950-51 to 2008-09. The estimation of vector error correction model based on VAR indicates the existence of long-run bidirectional causality between money supply and output and unidirectional causality from price level to money supply and output. But, in the short-run the bidirectional causality exists between money supply and price level and unidirectional causality exists from output to price level. The results infer that money is not neutral. Furthermore, inflation is a short-run monetary phenomenon. Gerlach and Tillmann (2011) examined the effect of inflation targeting on inflation persistence in Asia Pacific from 1985-2010. The study used quarterly data which spans the period 1985:1 to 2010:1 and is taken from the IMF's International Financial Statistics database. Countries included in the study are: Indonesia, Korea, the Philippines and Thailand, which all conduct monetary policy using inflation targeting. The study also presented estimates for China, Taiwan POC, Japan, Malaysia and Singapore that gear monetary policy to price stability without relying on inflation targeting. The study explored how successful this framework has been by looking at the persistence of inflation, as measured by the sum of the coefficients in an autoregressive model for inflation, using a median unbiased estimator and bootstrapped confidence bands. The result showed a significant reduction in inflation persistence following the adoption of inflation targeting. The speed by which persistence falls varies across countries. Interestingly, the economies not adopting inflation targeting do not show a decline in persistence. Measuring the performance of monetary policy strategies in terms of inflation persistence rather than the level of inflation shows that inflation targeting performs better than alternative strategies.

\section{Model Specification, Estimation Techniques and Data Description}

Model Specification: The Friedman-Lucas supply function provides a theoretical starting point for the test of Policy Ineffectiveness Proposition (PIP). The specification of this supply function is modified to accommodate the Central Bank of Nigeria use of interest rates as its primary monetary instruments. The money supply in the original equation is replaced with interest rate, (R). From monetary policy perspectives, the tested form of the Friedman-Lucas supply function with above modification is:

$\mathbf{Y}_{t}=\mathbf{a}_{0}+\mathbf{a}_{1}\left(\mathbf{R}_{\mathrm{t}}-\mathbf{R}_{\mathrm{t}}^{\mathrm{e}}\right)+\sum \mathrm{j}_{\mathrm{j}} \mathbf{Z}_{\mathrm{jt}}+\mu_{\mathrm{t}}$

Where:

$\mathrm{y}_{\mathrm{t}}=$ real output

$\mathrm{R}=$ nominal interest rate

$\mathrm{Re}^{\mathrm{e}}=$ expected nominal interest rate

$\mathrm{Z}_{\mathrm{t}}=$ matrix of other exogenous explanatory variables

$\mu_{\mathrm{t}}=$ random term

Equation (1) focuses on interest rate as the sole policy variable determining aggregate demand. Under rational expectations,

$\mathbf{R}_{\mathrm{e}}{ }^{\mathbf{t}}=\mathbf{E R}_{\mathbf{t}}$ (2)

Where $E R_{t}$ is proxied by its estimated value $E R_{t}=\widehat{R}$, therefore the estimated form of equation (1) becomes: $\mathbf{Y}_{\mathrm{t}}=\mathbf{a}_{\mathrm{o}}+\mathbf{a}_{1}\left(\mathbf{R}_{\mathrm{t}}-\widehat{R}\right)+\sum_{\mathrm{j}} \mathbf{a}_{\mathrm{j}} \mathbf{z}_{\mathrm{jt}}+\boldsymbol{\mu}_{\mathrm{t}} \quad \mathbf{a}_{1}>\mathbf{0}$

Equation (3) is the commonly used form of the modern classical output hypothesis for the short run. In the long run, $\mathrm{R}_{\mathrm{t}}=\hat{R}$ so that monetary policy changes cannot affect $\mathrm{y}$. In order to estimate equation (3), the value of $R{ }_{t}$ is needed. This is usually specified by the rational expectation hypothesis and its value is a function of the information available to the economic agent. In the case of Nigeria, the CBN implemented a monetary policy that gives a major role to inflation targeting, with an adoption of short term-term interest rates as the monetary policy instrument. In this context, the relevant knowledge would be that of the public on Central 
Bank behavior and on the policy rule that the Central bank follows in setting short-term interest rates. Assume that this rule gives the interest rate function as:

$\mathrm{Rt}=\sum_{\mathrm{i}} \boldsymbol{\alpha}_{\mathrm{i}} \mathrm{x}_{\mathrm{it}}$

Where $\mathrm{x}_{\mathrm{t}}$ is a set of exogenous and predetermined variables. Adding in a disturbance term $\eta_{\mathrm{t}}$ gives the interest rate rule function:

$\mathbf{R}_{\mathrm{t}}=\sum_{\mathrm{i}} \boldsymbol{\alpha}_{\mathrm{it}}+\eta_{\mathrm{t}}$

Under the Rational Expectation Hypothesis (REH), the public is assumed to know the policy function (4) and use the estimated values $\alpha_{\mathrm{i}}$ from (5) to calculate the estimated $\hat{R}$ value, where $\hat{R}$ is the rational expectations' proxy for the anticipated monetary policy, so that:

$\widehat{\eta}=\mathbf{R}_{\mathbf{t}}-\widehat{R}_{\mathbf{t}}$

Under the rational expectation hypothesis, $\hat{\eta}$ is the proxy for the unanticipated monetary policy.

The nested form of the Lucas model of equations (1) and (3) incorporates both $\hat{R}_{\mathrm{t}}$ and $\hat{\eta}_{\mathrm{t}}$ and specify the estimating equation as :

$\mathrm{y}_{\mathrm{t}}=\boldsymbol{\beta}_{\mathrm{o}}+\boldsymbol{\beta}_{1} \widehat{R}_{\mathrm{t}}+\beta_{2} \widehat{\eta}_{\mathrm{t}}+\sum_{\mathrm{j}} \gamma_{\mathrm{j}} \mathrm{z}_{\mathrm{jt}}+\mu_{\mathrm{t}}$

If $\hat{\beta}_{1}=0$, the anticipated values of monetary policy do not affect real output, so that this finding would be considered consistent with the modern classical hypothesis. But if $\hat{\beta}_{1}>0$, the modern classical hypothesis is rejected.

Barro (1977) proposed a test of the PIP hypothesis using two-step estimation procedure in the context of the Friedman-Lucas supply rule given above. In the first step, an empirical counterpart of the policy instrument function (equation 5) is estimated. A rule for a policy instrument specifies how the central bank will determine the value of its policy instrument, in this case, a short run interest rate. The use of interest rate as the operating monetary policy instrument is often espoused in the form of a Taylor rule (Taylor, 1993, 1999).The Taylor rule is a feedback rule according to which changes in two indicators, inflation ( $\pi$ ) and output gap (y), of the actual performance of the economy cause the central bank to change its policy rate (R) target, under this feedback rule, the central bank would increase its target policy rate if actual output ( or the demand for it) were too high or if inflation were too high, relative to their long-run or desired levels. Such a policy is sometimes depicted as one of "leaning against the wind". Taylor (1999) showed that variations in the CBN's policy instrument could be tracked by a simple three variable regression of the form:

$R_{t}=\alpha_{0}+\alpha_{1} R_{t-1}+\alpha_{2} \widehat{y}_{t}+\alpha_{3} \pi_{t}+\mu_{t}$

Where $\mathrm{R}$ is a short run nominal interest rate, $\pi$ is a measure of inflation and $\hat{y}$ is a measure of the output gap. Given the price stability and full employment pursuits of the Central bank, one would expect that $\alpha_{2}>0$ and $\alpha_{3}<0$. The lagged interest rate appears in (8) because of the tendency of central banks to try to smooth fluctuations in their policy instrument. With the presence of the lagged interest rate, the long run effect of an increase in inflation on the policy instrument is $\alpha_{3} /\left(1-\alpha_{1}\right)$. In order for monetary policy to stabilize the long run inflation rate, one would expect that the long run response of the nominal interest rate to inflation would be greater than one.

An issue actively pursued in further research on the Taylor rule has been whether or not exchange rate $(\varepsilon)$ should be included in this rule. The argument in favour of their inclusion is that shifts in them can change aggregate demand. Laurence Ball (2000), particularly argued that for open economies, the Taylor rule must be adjusted to take account of the real exchange rate. Doing so yields extended forms of the Taylor rule. Many empirical studies report that using some form of an augmented Taylor rule, such as incorporating changes in wealth or house prices or exchange rates leads to greater stabilization of the economy. Ncube and Mthokozisi (2010) argued that the inclusion of real exchange rate would enable an analysis of how the interest rate responds to real exchange rate changes. Similarly, Taylor (2000) points out that there exist a relationship between interest rate and the exchange rate through capital markets. Based on the foregoing, the CBN's policy reaction functions of the Taylor rule type, where observable short term nominal interest rate is determined as follows:

$R_{t}=\alpha_{0}+\alpha_{1} R_{t-1}+\alpha_{2} \widehat{y}_{t}+\alpha_{3} \pi_{t}+\alpha_{4} \varepsilon_{t}+\mu_{t}$ 
Where $\varepsilon$ is the real appreciation of the currency. Theory suggests that $\alpha_{4}$ should be negative for two reasons: first, depreciations will feed through to inflation and therefore will require a contractionary monetary policy response. Secondly, in open economies, a major way that monetary policy is transmitted to the real economy is through changes in the exchange rate, thus, a real depreciation is associated with expansionary monetary policy.

Since the agents are assumed to be rational, they know the underlying interest rate policy process and hence take into account the information espoused in equation (9) when forming expectations. Given this assumption, the predictable component of monetary policy is identified as that part of the process determining interest rate that could have been predicted on the basis of the information available at time $t$. The information available to agents at time $t$ consists of the values taken by the explanatory variables in the period $\mathrm{t}-1$. Since the monetary policy equation is estimated under the assumption of rational expectations, the lagged values of the explanatory variables have to be considered. The predictable component of monetary policy equation is considered as anticipated monetary policy. The error term in the equation should necessarily be a white noise and exhibit no serial correlation. If it did exhibit any systematic pattern, rational economic agents would have anticipated this in advance and would have exploited it. In this study, the error term in the monetary policy equation (which is unpredictable) is a measure of the unanticipated component of monetary policy. The second step of the Barro procedure utilized the anticipated and unanticipated monetary policy variables obtained from the first stage estimation of equation (5), alongside other explanatory variables to estimate the standard Friedman-Lucas supply function indicated in equation (1) above. The empirical counterpart of equation (1) is specified as follows:

$\ln \left(y_{t}\right)=\beta_{o}+\beta_{1} \ln \left(A R_{t}\right)+\beta_{2} \ln \left(U R_{t}\right)+\eta X_{t}+\varepsilon_{t}$

Where $\mathrm{AR}_{\mathrm{t}}$ and $\mathrm{UR}_{\mathrm{t}}$ measures anticipated and unanticipated monetary policy. $\mathrm{y}_{\mathrm{t}}$ is the growth rate of real GDP. $X_{t}$ is a vector of control variables that consists of inflation rate( $\left.\pi\right)$, unemployment (UNM) and exchange rate (EXC). By including all the control variables, equation (10) becomes:

$\ln \left(y_{t}\right)=\beta_{o}+\beta_{1} \ln \left(A R_{t}\right)+\beta_{2} \ln \left(U R_{t}\right)+\beta_{3} \ln \left(\pi_{t}\right)+\beta_{4} \ln \left(U N M_{t}\right)+\beta_{5} \ln \left(E C_{t}\right)+\varepsilon_{t}$

The growth rates of all variables of the model were constructed as the first difference of logarithmic transformation of the variable. The second step of the Barro procedure is implemented by estimating equation (11).

Estimation Technique: The study adopted Barro two step estimation procedure. The first step of Barro procedure uses Taylor policy rule that is estimated using Ordinary Least Square (OLS). The second step of Barro procedure adopts Auto-Regressive Distributed Lag (ARDL) approach for testing the existence of cointegration relationship among the variables as developed by Pesaran et. al. (2001). The approach has certain econometric advantages in comparison to other single cointegration procedures (Engle and Granger, 1987; Johansen, 1988; Johansen and Juselius, 1990). Firstly, endogeneity problems and inability to test hypotheses on the estimated coefficients in the long-run associated with the Engle-Granger (1987) method are avoided. Secondly, the long and short-run parameters of the model in question are estimated simultaneously. Thirdly, the econometric methodology is relieved of the burden of establishing the order of integration amongst the variables and of pre-testing for unit roots. The ARDL approach to testing for the existence of a long-run relationship between the variables in levels is applicable irrespective of whether the underlying regressors are purely I(0), purely I(1), or fractionally integrated. Finally, as argued in Narayan (2005), the small sample properties of the bounds testing approach are far superior to that of multivariate cointegration (Halicioglu, 2007). The approach, therefore, modifies the Auto-Regressive Distributed Lag (ARDL) framework while overcoming the inadequacies associated with the presence of a mixture of I(0) and I(1) regressors in a Johansen-type framework. The ARDL representation of equation (11) above is expressed as follows:

$\Delta \mathbf{y}_{\mathrm{t}}=\boldsymbol{\alpha}_{10}+\sum_{i=1}^{p} \alpha_{1 i} \Delta \mathbf{y}_{\mathrm{t}-\mathrm{i}}+\sum_{1=0}^{p} \alpha_{2 i} \Delta \mathrm{AR}_{\mathrm{t}-\mathrm{i}}+\sum_{1=0}^{p} \alpha_{3 i} \Delta \mathrm{UR}_{\mathrm{t}-\mathrm{i}}+\sum_{1=0}^{p} \boldsymbol{\alpha}_{4 i} \Delta \pi_{\mathrm{t}-\mathrm{i}}+\sum_{1=0}^{p} \alpha_{5 i} \Delta \mathrm{UMP}_{\mathrm{t}-\mathrm{i}}+$ $\sum_{i=0}^{p} \alpha_{6 i} \Delta \mathrm{EXC}_{\mathrm{t}-\mathrm{i}}+\beta_{10} \mathrm{y}_{\mathrm{t}-1}+\beta_{11} \mathrm{AR}_{\mathrm{t}-1}+\beta_{12} \mathrm{UR}_{\mathrm{t}-1}+\beta_{13} \pi_{\mathrm{t}-1}$

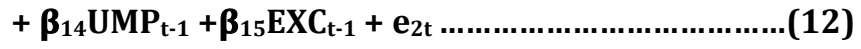

Where $\mathrm{e}_{2 \mathrm{t}}$ and $\Delta$ are the white noise term and the first difference operator, respectively. The ARDL method estimates $(p+1)^{k}$ number of regressions in order to obtain the optimal lag length for each variable, where $p$ is the maximum number of lags to be used and $\mathrm{k}$ is the number of variables in the equation. An appropriate lag 
selection based on a criterion such as Akaike Information Criterion (AIC) and Schwarz Bayesian Criterion (SBC). The ARDL co-integration method is based on the F or Wald-statistics. The F-test is used for testing the existence of long run relationship among. The null hypothesis is tested by considering the Unrestricted Error Correction Model in equation (12) while excluding the lagged variables $\Delta \mathrm{y}_{\mathrm{t}}, \Delta \mathrm{AR}_{\mathrm{t}}, \Delta \mathrm{UR}_{\mathrm{t}}, \Delta \mathrm{UNM}_{\mathrm{t}}, \Delta \pi_{\mathrm{t}}$ and $\Delta \mathrm{EXC}_{\mathrm{t}}$ based on the Wald or F-statistic. The asymptotic distribution of the F-statistic is non-standard under the null hypothesis of no co-integration relationship between the examined variables, without recourse to whether the underlying explanatory variables are purely I(0) or I(1). The null hypothesis of no co-integration $\left(\mathrm{H}_{0}: \boldsymbol{\beta}_{10}=\boldsymbol{\beta}_{11}=\boldsymbol{\beta}_{12}=\boldsymbol{\beta}_{13}=\boldsymbol{\beta}_{14}=\boldsymbol{\beta}_{15}\right)$ is therefore tested against the alternative hypothesis $\left(\mathrm{H}_{1}: \boldsymbol{\beta}_{10} \neq \boldsymbol{\beta}_{11} \neq \boldsymbol{\beta}_{12} \neq\right.$ $\boldsymbol{\beta}_{13} \neq \boldsymbol{\beta}_{14} \neq \boldsymbol{\beta}_{15}$ ). Thus, Pesaran et al. (2001) compute two sets of critical values for a given significance level. One set assumes that all variables are I(0) and the other set assumes they are all I(1). If the computed Fstatistic exceeds the upper critical bounds value, then the $\mathrm{H}_{0}$ is rejected. If the F-statistic is below the lower critical bounds value, it implies no co-integration. Lastly, if the F-statistic falls into the bounds then the test becomes inconclusive. Consequently, the order of integration for the underlying explanatory variables must be known before any conclusion can be drawn.

If there is evidence of co-integration among the variables, the following long-run model is estimated:

$\Delta \mathbf{y}_{\mathrm{t}}=\boldsymbol{\alpha}_{1}+\sum_{i=\mathbf{1}}^{p} \boldsymbol{\theta}_{1 i} \Delta \mathbf{y}_{\mathrm{t}-\mathrm{i}}+\sum_{1=\mathbf{0}}^{p} \boldsymbol{\delta}_{1 i} \Delta \mathbf{A R}_{\mathrm{t}-\mathrm{i}}+\sum_{\mathbf{1 = 0}=0}^{p} \lambda_{1 i} \Delta \mathbf{U R}_{\mathrm{t}-\mathrm{i}}+\sum_{1=0}^{p} \omega_{1 i} \Delta \pi_{\mathrm{t}-\mathrm{i}}+\sum_{\mathbf{1}=\mathbf{0}}^{p} \boldsymbol{\beta}_{1 i} \Delta \mathbf{U M P}_{\mathrm{t}-\mathrm{i}}+$

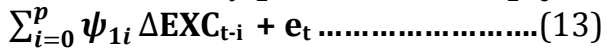

The ARDL specification of the short-run dynamics can be derived by constructing an error correction model of the form:

$\Delta \mathbf{y}_{\mathrm{t}}=\boldsymbol{\alpha}_{2}+\sum_{i=\mathbf{1}}^{p} \boldsymbol{\beta}_{2 i} \Delta \mathbf{y}_{\mathrm{t}-\mathrm{i}}+\sum_{1=0}^{p} \omega_{2 i} \Delta \mathbf{A R}_{\mathrm{t}-\mathrm{i}}+\sum_{\mathbf{1}=\mathbf{0}}^{p} \boldsymbol{\lambda}_{2 i} \Delta \mathbf{U R}_{\mathrm{t}-\mathrm{i}}+\sum_{1=\mathbf{0}}^{p} \boldsymbol{\delta}_{2 i} \Delta \boldsymbol{\pi}_{\mathrm{t}-\mathrm{i}}+\sum_{1=\mathbf{0}}^{p} \boldsymbol{\theta}_{2 i} \Delta \mathbf{U M P}_{\mathrm{t}-\mathrm{i}}+$

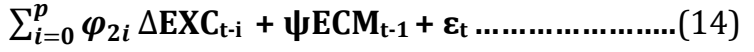

Where $\mathrm{ECM}_{\mathrm{t}}$ is the error correction term and is defined as:

$\mathbf{E C M}_{\mathrm{t}}=\Delta \mathbf{y}_{\mathrm{t}}-\boldsymbol{\alpha}_{1}-\sum_{i=\mathbf{1}}^{p} \boldsymbol{\theta}_{1 i} \Delta \mathbf{y}_{\mathrm{t}-\mathrm{i}}-\sum_{1=0}^{p} \boldsymbol{\delta}_{1 i} \Delta \mathbf{A R}_{\mathrm{t}-\mathrm{i}}-\sum_{1=0}^{p} \lambda_{1 i} \Delta \mathbf{U R}_{\mathrm{t}-\mathrm{i}}-\sum_{1=0}^{p} \omega_{1 i} \Delta \pi_{\mathrm{t}-\mathrm{i}}-\sum_{1=0}^{p} \boldsymbol{\beta}_{1 i} \Delta \mathbf{U M P}_{\mathrm{t}-\mathrm{i}}-$

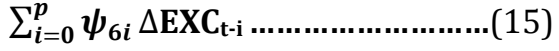

All coefficients of the short-run equation are coefficients relating to the short-run dynamics of the model's convergence to equilibrium and $\psi$ in equation (14) above represents the speed of adjustment.

In order to examine the effect of monetary policy shocks on real activities in Nigeria, this study used quarterly data over the period of 2000:1 to 2010:4, containing six variables viz: outputs (proxied by GDP), anticipated monetary policy, unanticipated monetary poliy, real exchange rate, unemployment rate and consumer price index that was used to measure prices $(\pi)$. Anticipated and unanticipated monetary policies were generated by estimating Taylor policy rule. The predictable component of the Taylor's rule regression result was used as the anticipated monetary policy while the error term was used as the unanticipated monetary policy. An estimate of output gap variable $(\hat{y})$ was required to estimate the policy equation. This was constructed as the natural $\log$ of the ratio of trend output, $\mathrm{Y}_{\mathrm{T}}$, to real output, $\mathrm{y}$. Trend real output was estimated using a HodrickPrescott filter on the output data. As regards the measurement of real output (Y), real Gross Domestic Output which is available in the CBN statistical bulletin was used. The treasury bill rate was chosen as the measure of short term interest rate (R) reflecting the measures of monetary policy. The adoption of the treasury bill rate as the policy variable rather than the minimum rediscount rate (MRR) was justified based on fundamental limitation of this variable. For instance, the minimum rediscount rate which could have otherwise served as a policy variable was an administered rate that changed only as a delayed response to already existing information. Since the variable changed less frequently, one could hold that it did not play an important role in the central bank's policy decisions (Leeper, Sims and Zha, 1996). Other macroeconomic variables such as real effective exchange rate, unemployment rate and consumer price index were used as stated in the CBN statistical bulletin of 2010 .

\section{Estimation and Interpretation of Result}

The test for the stationarity status of all variables to determine their order of integration is necessary before proceeding with the ARDL bounds test, although the bounds testing procedure is not predicated on prior information about the order of integration of the series under investigation. This is however expedient to ensure that the variables are not I(2) stationary so as to avoid spurious results. Inferences in the bounds 
testing procedure through the computed F-statistics for bounds testing are based on the assumption that the variables are level or first-differenced stationary. For this purpose, the ADF and PP methods are used to determine the stationarity of the variables and the results are presented in table 1.

Table 1: Summary of Unit Root Test

\begin{tabular}{lllllll}
\hline Variables & $\begin{array}{l}\text { Augmented Dickey-Fuller } \\
\text { Level }\end{array}$ & $\begin{array}{c}\mathbf{1}^{\text {st }} \\
\text { difference }\end{array}$ & Remarks & $\begin{array}{l}\text { Philip-Perron } \\
\text { Level }\end{array}$ & $\begin{array}{l}\text { 1 } \\
\mathbf{1}^{\text {st }} \\
\text { difference }\end{array}$ & Remarks \\
\hline AR & -1.295753 & $-2.185081^{*}$ & $\mathrm{I}(1)$ & -1.620159 & $-3.849751^{*}$ & $\mathrm{I}(1)$ \\
UR & -2.446970 & $-6.113761^{*}$ & $\mathrm{I}(1)$ & -3.850155 & -8.294533 & $\mathrm{I}(1)$ \\
INFLATION & -2.739637 & $-4.822051^{*}$ & $\mathrm{I}(1)$ & $-4.453630^{*}$ & $-12.57221^{*}$ & $\mathrm{I}(1)$ \\
REXC & -1.570916 & $-6.238000^{*}$ & $\mathrm{I}(1)$ & -1.606956 & $-6.235144^{*}$ & $\mathrm{I}(1)$ \\
RGDP & 0.517688 & $-5.182650^{*}$ & $\mathrm{I}(1)$ & -1.106467 & $-10.45885^{*}$ & $\mathrm{I}(1)$ \\
UNEMP & -1.728947 & $-2.689118^{* * *}$ & $\mathrm{I}(1)$ & -0.809829 & $-2.856806^{* * *}$ & $\mathrm{I}(1)$ \\
\hline
\end{tabular}

$\bar{*} /^{* *} /{ }^{* * *}$ represent stationary at 1,5 and 10 percent level respectively.

The Unit root test on all variables was carried out using the Augmented Dickey-Fuller(ADF) and PhillipPerron (PP) tests with intercept only and the result was presented in Table 1. The result showed that all variables were non-stationary at levels. That is, they were not integrated at order zero but they became stationary after first differencing. The PP unit root test results as reported in Table 1 confirmed results from ADF test.

Table 2: ARDL Bounds test for Cointegration

\begin{tabular}{|c|c|c|}
\hline Model & F-S & \\
\hline F(oil, inf,rexc,une & nt,unant) & \\
\hline Critical Values & Upper Bound & Lower Bound \\
\hline & $K=7 ; n=41$ & \\
\hline $10 \%$ & 3.1392 & 1.9118 \\
\hline $5 \%$ & 3.6807 & 2.2942 \\
\hline
\end{tabular}

Narayan (2005): Critical values for the bounds test: case III: unrestricted intercept and no trend. The critical values reported in Pesaran et al. (2001) are based on large sample sizes; thus, it cannot be used for small sample sizes. Narayan (2004 a, b ) generates and reports new sets of critical values for small sample sizes ranging from 30 observations to 80 observations. Table 2 reports the results of the ADRL bounds cointegration tests. It shows the calculated F-statistic when the regression is normalized on the economic growth. The search for co-integrating relations has been restricted to growth variable as the dependent variable based on the fact that the study strictly utilized a growth regression model. The computed $F$-statistic (33.3842) is higher than the upper critical bound at $5 \%$ and $10 \%$ critical values as indicated in Table 2 . This provided evidence to reject the null hypothesis of no co-integration at $5 \%$ and $10 \%$ significance level for the growth model. It can therefore be concluded from the ARDL bounds test that there is a long-run relationship among the variables. Following the establishment of long-run co-integration relationship among the variables, the long-run and short-run dynamic parameters for the variables were obtained. The empirical results of the long-run model are presented in Table 3, while the results of the error correction model are presented in Table 4. 
Table 3: Estimated ARDL Long-Run Coefficients. Dependent Variable: RGDP ARDL $(1,1,1,1,1,1,0)^{\mathrm{a}}$

\begin{tabular}{lccc}
\hline Regressor & Coefficient & t-statistics & P-value \\
\hline$\pi$ & 54276 & 2.0517 & 0.049 \\
REXC & 11406.1 & 2.1294 & 0.042 \\
UMP & -89624.2 & -2.0261 & 0.052 \\
AR & 162652.7 & 2.7959 & 0.009 \\
UR & 6695 & 0.15851 & 0.875 \\
\hline
\end{tabular}

A. Selected based on Schwarz Bayesian Criterion: The estimated coefficients of the long-run relationship of the effects of monetary policy shocks on output and prices growth produced mixed results in line with the diversity of evidence of existing literature. The long-run ARDL estimates indicate positive and significant effects of anticipated monetary policy on output in Nigeria. This is in line with the findings of Yamak and Küçükkale (1998) and Odedokun (1988) conducted in Turkey and Nigeria respectively. They found that anticipated rather than unanticipated monetary policy exerted a significant impact upon real economic activity Unanticipated monetary policy is correctly signed but statistically insignificant. This shows unanticipated monetary policy has no impact on real variables in Nigeria. This is against the findings of studies like Saibu and Oladeji (2008) and Alogoskoufis (1982) that unanticipated monetary policy had significant effect on real variables in Nigeria and Greece.

Table 4: Error Correction Representation for the Selected ARDL Model ARDL $(1,1,1,1,1,1,0)^{a}$

\begin{tabular}{llll}
\hline Regressors & Coefficients & t-statistic & P-value \\
\hline$\Delta$ Oil & 0.24150 & 6.6340 & 0.000 \\
$\Delta \pi$ & -33228.2 & -6.2856 & 0.000 \\
$\Delta \operatorname{Rexc}$ & 6507.2 & 3.1762 & 0.003 \\
$\Delta \mathrm{Ump}$ & -70100 & -3.2735 & 0.002 \\
$\Delta \mathrm{AR}$ & 4832.2 & 0.5918 & 0.558 \\
$\Delta \mathrm{UR}$ & 1463.5 & 0.1545 & 0.878 \\
Ecm $(-1)$ & -0.2185 & -2.9304 & 0.006 \\
\hline
\end{tabular}

Selected based on Schwarz Bayesian Criterion

Table 4 gives the results of the short-run dynamic coefficients associated with the long-run relationships obtained from the ECM equation. The error correction terms in the models are highly significant and correctly signed. This indicates adjustment to long-term equilibrium in the dynamic model. Bannerjee et al (1998) posits this as an evidence of a stable long-term relationship. The coefficients of error correction term are (0.2185 ) . This implies that deviations from the long-term growth rate in output adjust quickly. Specification problems associated with serial correlation, functional form, normality or heteroscedasticity were checked with diagnostics tests, including the test for serial correlation (LM test), heteroscedasticity (ARCH test), normality (JB (N)) and functional form. The results are presented in table 5 below.

Table 5: ARDL - VECM Model Diagnostic tests

\begin{tabular}{ll}
\hline Test Statistics & LM $\left(\chi^{2}\right)$ \\
\hline Serial Correlation & $\chi^{2}(4)=28.5699(0.60)$ \\
Functional Form & $\chi^{2}(1)=3.6798(0.060)$ \\
Normality & $\chi^{2}(2)=0.78193(0.676)$ \\
Heteroscedasticity & $\chi^{2}(1)=0.35490(0.551)$ \\
\hline
\end{tabular}

Table 5 indicates the underlying ARDL equation passes the diagnostic tests. The stability of the long-run coefficients, along with the short run dynamics of the estimated ARDL model were confirmed with the test of CUSUM . Table 6 presents the plots of the CUSUM based on the Schwarz Bayesian criterion. As can be seen in 
Figure 1, the plot remains within critical bounds at 5\% significance, accepting the null hypothesis that all coefficients and the ECM are stable.

Figure 1: Plot of Cumulative Sum of Recursive Residuals

Plot of Cumulative Sum of Recursive Residuals

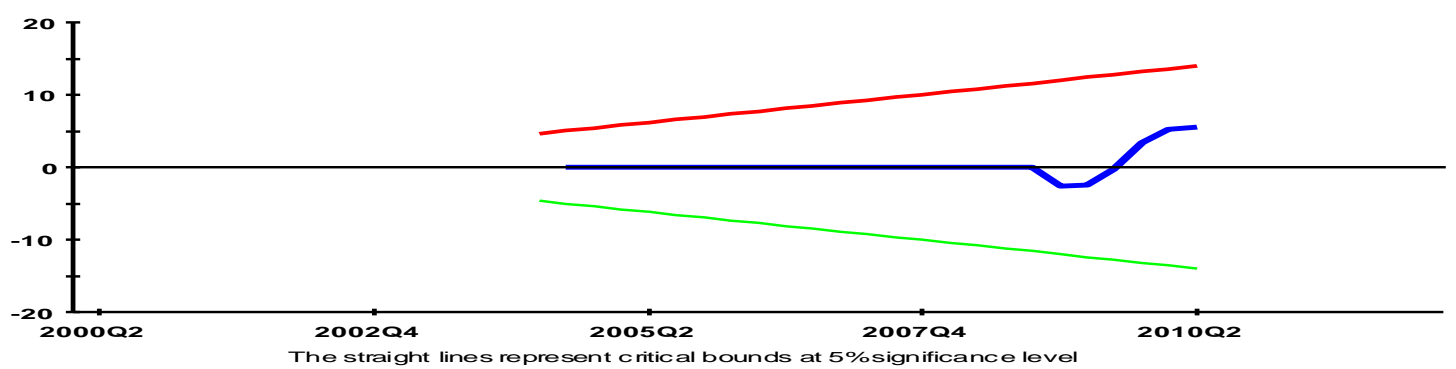

\section{Conclusion}

The study provides a contribution to the empirical controversy of the monetary policy actions and macroeconomic variables nexus., by an empirical analysis of the issue in Nigeria. The study utilized quarterly data from 2000 to 2010. The long-run ARDL estimates indicate a positive and significant effects of anticipated monetary policy on output and prices in Nigeria while unanticipated monetary policy is not significant. This implies anticipated monetary policy and not unanticipated monetary policy affects output and prices in Nigeria. This findings shows PIP did not hold as suggested by Lee and Zilberfarb (1993) that the crucial assumptions of the PIP are not necessarily valid for developing economies, given the fact that a large degree of government intervention in these countries might hinder quick adjustment of wages and prices thereby preventing market clearing. The study therefore suggested that the use of a one fit for all policy instrument in stimulating output growth and prices in the economy rather than using one specific measures could also be attributed to the failure of monetary policy in Nigeria. While the aggregate of evidence invalidates rational expectations' PIP proposition in Nigeria, doubts exist regarding the capacity of an inflation targeting monetary policy in curbing inflationary pressures in the economy. Thus, for policy implications, this study supports calls for supplementing the inflation targeting framework with targets for other real variables, such as exchange rates and employment.

\section{References}

Alogoskoufis, G. S. (1982). Unanticipated Money, Output and Prices in Greece. European Economic Review, 19(1-2), 289-303.

Ball, L. (2000). Policy Rules and External Shocks, NBER Working Paper 7910.

Bannerjee, A., Dolado, J. \& Mestre, R. (1998). Error-correction mechanism tests for cointegration in single equation framework. J. Time Series Analysis, 19, 267-83.

Barro, R. J. (1977). Unanticipated Money Growth and Unemployment in the United States. American Economic Review, 67(2), 101-115.

Barro, R. J. \& Rush, M. (1983). Unanticipated Money and Economic Activity, in Rational Expectations and Economic Policy, Ed. By S. Fischer, Chicago: University of Chicago Press.

Bernanke, B. S. \& Woodford, M. (1997). Inflation Forecasts and Monetary Policy. Journal of Money, Credit and Banking, Blackwell Publishing, 29(4), 653-84.

Chimobi, O. P. \& Uche, U. C. (2010). Money, Price and Output. A Causality Test for Nigeria. American Journal of Scientific Research, 8, 78-87.

Dickey, D. A. \& Fuller, W. A. (1979). Distribution of the Estimators for Autoregressive Time Series with a Unit Root. Journal of the American Statistical Association, 74, 427-431.

Folawewo A. O. \& Osinubu, T. S. (2006). Monetary Policy and Economic Instability in Nigeria. A Rational Expectation Approach. Journal of Social Sciences, 12(2), 93-100.

Gerlach, S. \& Tillmann, P. (2011). Inflation Targeting and Inflation Persistence in Asia-Pacific. Hong Kong Institute for Monetary Research Working Paper No.25/2011. 
Gujarati, D. N. \& Porter, D. C. (2009). Basic Econometrics International Edition, 2009, ISBN: 978-007-1276252

Johansen, S. \& Juselius, K. (1990). Maximum likelihood estimation and inference on cointegration - with application to the demand for money. Oxford Bulletin of Economics and Statistics, 52, 169-210.

Kuttner, K. N. \& Posen, A. S. (1999). Does talk matter after all? Inflation targeting and central bank behavior. Federal Reserve Bank of New York Staff Report, 88(1).

Lee, Y. G. \& Zilberfarb, B. Z. (1993). Unanticipated Money, Output, Employment and Price in A Developing economy: The Korean case. International Economic Journal, 7(2).

Lucas, R. E. (1972). Expectation and the Neutrality of Money. Journal of Economic Theory, 4, 103-124.

Mishkin, F. (2000). Financial stability and the Macroeconomy, Economics working paper 09, Department of Economics, Central bank of Iceland.

Mishkin, F. (2002). The Role of Output Stabilization in the Conduct of Monetary Policy. International Finance, Blackwell Publishing, 5(2), 213-27.

Mishra, P. K., Mishra, U. S. \& Mishra, S. K. (2010). Money, Price and Output: A Causality Test for India. International Research Journal of Finance and Economics, 53(2).

Muhd Zulkhibri, A. M. (2007). Causality link between Money, Output and Prices in Malaysia; an Empirical Reexamination. Applied Econometrics and International Development, 7(1).

Nelson, C. \& Plosser, C. (1982). Trends and Random Walks in Macroeconomics Time Series: Some Evidence and Implications. Journal of Monetary Economics, 10, 139-162.

Ncube, M. \& Mthokozisi, T. M. (2010). Monetary Policy Conduct Based on Nonlinear Taylor Rule: Evidence from South Africa. Working Papers Series $N^{\circ} 113$, African Development Bank, Tunis, Tunisia.

Neumann, M. J. M. \& von-Hagen, J. (2002). Does inflation targeting matter? Federal Reserve Bank of St. Louis Review, 85, 127-148.

Odedokun, M. O. (1998). An Econometric Investigation of Monetary Neutrality In Nigeria. Nigeria Journal of Social Studies, 3, 313-334.

Ogungbenro, I. O., Adebayo, A. A. \& Amekodo, O. T. (1995). Unemployment and Monetary Policy in Nigeria: An Econometric Analysis 1960-1993. First Bank Review, 3, 12-21.

Owoye, O. \& Onafowora, O. A. ( 2007). M2 Targeting, Money Demand, and Real GDP Growth In Nigeria: Do Rules Apply? Journal of Business and Public Affairs, 1(2).

Saibu, F. \& Oladeji, L. (2004). Monetary Policy and Inflation Control: The Relevance of Rational Expectation Hypothesis in Contemporary Nigeria. The India Journal of Economics, LXXXIV(335), 555-568.

Saibu, M. O. \& Oladeji, S. I. (2008b). Openness and the Effects of Fiscal and Monetary Policy Shocks on Real Output in Nigeria (1960-2003). African Development Review, 20(3), 529-548.

Sargent, J. T. \& Wallace, I. (1975). Rational Expectation, the Optimal Monetary instrument And Money Supply Rule. Journal of political Economy, 83, 341-355.

Taylor, J. B. (1993). Discretion versus Policy Rules in Practice. Carnegie-Rochester Conference Series on Public Policy, 39, 195-214.

Taylor, J. B. (1999). Monetary Policy Rules. Chicago: University of Chicago.

Yamak, R. \& Küçükkale, Y. (1998). Anticipated versus Unanticipated money in turkey. Yapi Kredi Economic Review, 9(1), 15-25. 